\title{
PDZ and LIM Domain Protein 2
}

National Cancer Institute

\section{Source}

National Cancer Institute. PDZ and LIM Domain Protein 2. NCI Thesaurus. Code C105697.

PDZ and LIM domain protein 2 (352 aa, $37 \mathrm{kDa}$ ) is encoded by the human PDLIM2 gene. This protein is involved in actin binding, cell migration and cell adhesion. 